\title{
Evaluation of liver function tests and C-reactive protein in COVID-19 (SARS Cov-2) positive patients diagnosed by Real-time PCR
}

AUTHOR NAMES: Fatima Khurshid (B.Sc.) ${ }^{1}$, Dr Sajjad Iqbal (PhD) ${ }^{2}$, Madiha Mumtaz (PhD) ${ }^{3}$. AUTHOR AFFILIATIONS:

${ }^{1,2}$ Shalamar Medical and Dental College, Lahore, Pakistan, ${ }^{3}$ School of Biological Sciences, University of the Punjab, Lahore-54590, Pakistan.

CORRESPONDING AUTHOR EMAIL ADDRESS: Fatima Khurshid Fatima.khurshid43@gmail.com

DECLARATION OF AUTHOR'S COMPETING INTERESTS: The authors declare that they have no known competing financial interests or personal relationships that could have appeared to influence the work reported in this paper.

\section{ABSTRACT}

BACKGROUND AND AIMS: The SARS-CoV-2 pandemic, has caused an unconventional social and economic impact globally. To date, there was limited data regarding the effect of COVID-19 infection on the trend of RT-PCR Ct value, risk factors for disease, effect on liver enzymes, etc. This study aimed to assess the frequency of COVID-19 infection in different age groups and genders. Association of cycle threshold $(\mathrm{Ct})$ values with disease severity and to describe the effect of COVID-19 infection on LFT, Deritis ratio, and CRP. That can be used as indicators for COVID-19 infection diagnosis, the guidance for treatment decisions, and prognosis in infected individuals.

METHODS: This was a cross-sectional study conducted in the Molecular Biology and Chemical Pathology sections of the Pathology Department, Shalamar Teaching Hospital Lahore from November 2020 to March 2021.

RESULTS: Males $51 \%$ were more likely to be infected by SARS-CoV-2. Most of the infected individuals $36.5 \%$ were in the age group 20-40. Age and underlying comorbidities are important factors that play a significant role in COVID-19 severity. The uppermost number of the patients had symptoms of 
medRxiv preprint doi: https://doi.org/10.1101/2021.09.29.21264304; this version posted October 1, 2021. The copyright holder for this preprint (which was not certified by peer review) is the author/funder, who has granted medRxiv a license to display the preprint in perpetuity.

It is made available under a CC-BY 4.0 International license.

fever $78.3 \%$, cough $50.4 \%$ and myalgias $50.1 \%$ RT-PCR low Ct value could be an important indicator related with the disease severity and mortality risk p value $<0.001$ and 0.003 respectively. Bilirubin indirect, ALT, AST, and CRP were significantly associated with disease severity. Deritis ratio and CRP was found to be significantly associated with the risk of mortality.

CONCLUSIONS: Real-Time PCR results along with Ct values for SARS-CoV-2 may have benefit for clinicians in patient management decisions. Several risk factors e.g., age and comorbidities for developing severe disease and mortality risk have been identified. These biochemical laboratory parameters ALT, AST, Deritis ratio and CRP can be used as predictive biomarkers for progression towards severe disease and risk of mortality.

KEY WORDS: RT-PCR, SARS-CoV-2, LFT, CRP

\section{INTRODUCTION}

Before 2019 ends, an obscure infection that causes pneumonia like symptoms and lung fibrosis arose. The outbreak was originated in Wuhan City, Hubei province of China. This pneumonia of unknown etiology was reported to World Health Organization (WHO) on $31^{\text {st }}$ December 2019. ${ }^{(1,2)}$ Initially WHO named it as 2019-novel coronavirus (2019-nCoV) on January 12, 2020 after that on the basis of phylogenetic analysis International Committee on Taxonomy of Viruses officially named it as severe acute respiratory syndrome 2 (SARS-CoV-2) on 11 February $2020 .^{(3,4)}$ It continues to spread around the globe, and within 5 months, more than 2.6 million people are infected with this virus. ${ }^{(5)}$ This SARS-CoV-2 was declared as a pandemic by WHO on 11 March 2020. It was the fifth pandemic after the flu in $1918 .^{(4,6)}$

The coronavirus has been previously known for causing Severe Acute Respiratory Syndrome (SARS$\mathrm{CoV}$ ) and Middle East Respiratory Syndrome (MERS-CoV) outbreaks respectively. ${ }^{(7)}$ The novel coronavirus that is emerged recently, is responsible for coronavirus disease 2019 (COVID-19), and named Severe Acute Respiratory Syndrome Coronavirus-2 (SARS-CoV-2) is thought to be more infectious as compared to SARS and MERS-CoV. ${ }^{(7)}$ 
medRxiv preprint doi: https://doi.org/10.1101/2021.09.29.21264304; this version posted October 1, 2021. The copyright holder for this preprint (which was not certified by peer review) is the author/funder, who has granted medRxiv a license to display the preprint in perpetuity.

It is made available under a CC-BY 4.0 International license .

Coronavirus disease (COVID-19) is a leading public health concern these days. ${ }^{(8,9)}$ Pakistan, alongside many other countries is also confronting the historic public health emergency these days. ${ }^{(7)}$ The classical symptoms of COVID-19 are fever, pneumonia, dry cough, and myalgia, and even though can cause alveolar damage which can lead to progressive respiratory failure. ${ }^{(10)}$ About $81 \%$ of patients of SARSCoV-2 had asymptomatic or mild disease, $14 \%$ progress to severe disease can present with pneumonia or respiratory distress and need medical care, and just 5\% of hospitalized patients need intensive care units. $^{(7)}$

The estimated mean incubation period for SARS-CoV-2 is 4 to 6 days, as compared to SARS-CoV in which the mean incubation period was 4.4 days and 5.5 days in MERS-CoV respectively. It is also observed that out of 10,000 infected individuals 64 may develop symptoms after the quarantine period of 14-day. Present studies suggest that older individuals and those with weak immune systems from underlying comorbidities are more prone to develop severe forms of COVID-19. ${ }^{(11)}$

Person-to-person contact and respiratory droplets are the primary sources of SARS-CoV-2 transmission. ${ }^{(10)}$ The inhaled virus binds the epithelial cells present in the nasal cavity and starts replication. The primary receptor for $2019-\mathrm{nCoV}$ is angiotensin-converting enzyme 2 (ACE2) that is a metalloprotease and expressed in the lung, cardiac, liver, intestine, vascular endothelium, and kidney cells. $^{(8,12)}$

Rapid detection of SARS-CoV and SARS-CoV-2 is done through nucleic acid amplification test (NAAT) by real-time reverse-transcription polymerase chain reaction (RT-PCR) or Enzyme immunoassay (EIA) for antigen detection. Because Serum IgA, IgM, and IgG and will appear simultaneously, between days 5 and 17 afterward the onset of symptoms but the gold standard for diagnosis is RT-PCR. ${ }^{(12,13)}$ Throat washings and nasopharyngeal swabs preserved in viral transport medium (VTM) remain the key diagnostic samples for PCR diagnosis. ${ }^{(12,14)}$ 
medRxiv preprint doi: https://doi.org/10.1101/2021.09.29.21264304; this version posted October 1, 2021. The copyright holder for this preprint (which was not certified by peer review) is the author/funder, who has granted medRxiv a license to display the preprint in perpetuity.

It is made available under a CC-BY 4.0 International license.

In RT-PCR the cycle threshold $(\mathrm{Ct})$ values denote the amplification cycles number, which is necessary for the target gene to surpass a threshold level. It is the indirect method of quantifying the viral RNA copies number in the sample or in other words a semi-quantitative measure of the viral load so Ct value had an inverse relationship with the viral load. Nevertheless, the Ct value is only a proxy for viral load because several factors e.g. the assay itself or the factors in the sample matrix can affect the amplification efficiency. $^{(15)}$

The genome of SARS-CoV-2 codes for four main structural proteins: spike (S), membrane (M), envelope $(\mathrm{E})$, nucleocapsid $(\mathrm{N})$ of which the spike $(\mathrm{S})$ protein plays a major part in receptor recognition and the cell membrane fusion. The $\mathrm{S}$ protein typically present in a prefusion, metastable form when the virus connects with the cells of host extensive structural change occurs in the $S$ protein that allows the virus to fuse with the cell membrane of the host. ${ }^{(16,17)}$ Interestingly, patients diagnosed with COVID-19 infection also had variable grades of hepatic damage/dysfunction besides the acute respiratory symptoms. ${ }^{(18)}$

Involvement of the liver in COVID-19 could be due to an unrestrained immune response, direct cytopathic effect of the virus, drug-induced hepatic injury, or sepsis. ACE2 receptors are generously distributed in type 2 alveolar cells and the suggested mechanism of virus entrance is also through ACE2 receptors of the host. Interestingly, ACE2 receptors are also present in the vascular endothelium, enteric tract, and liver cholangiocyte. Most of the patients develop elevated transaminases regardless of the presence of ACE2 receptors in cholangiocytes. ${ }^{(19)}$

The C-Reactive Protein (CRP) induced by interleukin-6 (IL-6) in the liver is a non-specific acute-phase protein, and is a sensitive biomarker of inflammation, tissue damage and infection. The expression level of CRP is generally low but increases spontaneously and significantly during an acute inflammatory response. Elevated CRP in isolation or conjunction with other parameters may indicate a viral or non-viral infection. The inflammatory response plays an important role in COVID-19 infection and inflammatory cytokine storm also increases the severity of infection. ${ }^{(14)}$ 
medRxiv preprint doi: https://doi.org/10.1101/2021.09.29.21264304; this version posted October 1, 2021. The copyright holder for this preprint (which was not certified by peer review) is the author/funder, who has granted medRxiv a license to display the preprint in perpetuity.

It is made available under a CC-BY 4.0 International license.

This is the era of life-threatening viral respiratory infections where human beings are at the leading edge in dealing with such viruses as SARS, MERS, avian influenza H5N1, and H7N9. ${ }^{(20)}$ Recently emerged SARS-CoV 2 has become a public health emergency now a days. Possible signs and symptoms, clinical outcomes, and variations in biochemical markers in our population, that can be used as potential indicators for the disease and those may help the clinicians in diagnosis and direction for the appropriate treatment.

\section{METHODS}

This was a cross-sectional study among patients of Shalamar Teaching Hospital, Lahore. From November 2020 to March 2021 total 345 tested positive for COVID-19 infection by RT-PCR were included in the study. All patients provided informed consent. It was not appropriate or possible to involve patients and the public in the design, conduct, or reporting of our research.

\section{Liver function test (LFT) and C-Reactive Protein (CRP):}

Blood samples of all patients were taken from the venous blood by phlebotomists. Centrifugation was performed at $5000 \mathrm{rpm}$ for 10 minutes to obtain serum. LFT, CRP was performed by photometric and particle enhanced immunoturbidimetric assay respectively. LFT and CRP abnormalities were defined as the elevation or reduction from the mentioned ranges: bilirubin direct $(0.10-0.40 \mathrm{mg} / \mathrm{dl})$, bilirubin indirect $(0.10-0.70 \mathrm{mg} / \mathrm{dl})$, alkaline phosphatase (ALP) $(40.00-135.00 \mathrm{U} / \mathrm{L})$, alanine aminotransferase $(\mathrm{ALT})(5.00-40.00 \mathrm{U} / \mathrm{L})$ aspartate aminotransferase $(\mathrm{AST})(5.00-40.00 \mathrm{U} / \mathrm{L})$, albumin $(3.50-5.00$ $\mathrm{g} / \mathrm{dl})$, proteins total $(6.30-8.30 \mathrm{~g} / \mathrm{dl})$, gamma G.T (GGT) $(5.00-50.00 \mathrm{U} / \mathrm{L})$, deritis ratio was calculated AST/ALT (1.00), CRP > 5.00mg/dl.

\section{Statistical analysis}

Categorical variables were described as frequency and percentages, and continuous variables as mean and SD. Comparison of categorical variables was done using the Chi-square or the Fisher exact test if the cell counts were small. One way ANOVA was used to explore the association between liver test abnormalities 
medRxiv preprint doi: https://doi.org/10.1101/2021.09.29.21264304; this version posted October 1, 2021. The copyright holder for this preprint (which was not certified by peer review) is the author/funder, who has granted medRxiv a license to display the preprint in perpetuity.

It is made available under a CC-BY 4.0 International license .

and the severity of the disease. A p value of less than 0.05 was considered statistically significant. All statistical analyses were performed using SPSS version 22.0 software.

\section{Ethical Approval}

The study was approved by the Institutional Ethical Review Board, Shalamar Medical and dental college (SMDC-IRB/AL/60/2020).

\section{RESULTS}

A total of 345 COVID-19 patients confirmed by RT-PCR were included in this study. Mean Ct value RTPCR was 15.2 \pm 6.60 . Male's patients were $51 \%(\mathrm{~N}=176)$ while $49.0 \%(\mathrm{~N}=169)$ were females. The mean age was $47.5 \pm 17.3$ years. Most of the infected individuals $36.5 \%$ were in the age group 20-40 (Figure 1). The highest number of the patients had symptoms of fever $78.3 \%$, cough $50.4 \%$ and myalgias $50.1 \%$ (Figure 2). All the patients were classified into mild, moderate, and severe categories on the basis of symptoms as per WHO interim guidance 27 may 2020. The highest percentage of patients $47.02 \%$ were in the mild category whereas, $33.30 \%$ moderate, $10.70 \%$ asymptomatic, $7.70 \%$ were severe. Of 345 patients 117 had underlying comorbidities, most of the patients were diabatic $15.4 \%$, hypertensive $9.6 \%, 5.80 \%$ cardiac patients, $2.00 \%$ asthma, $1.60 \%$ have chronic kidney disease and $0.30 \%$ had tumors.

Table 1 shows that age and underlying comorbidities (diabetes, hypertension, heart and kidney disease, tumors) are important factors that play a significant role in COVID-19 severity. Besides that, RT-PCR Ct value also has a significant association with disease severity $\mathrm{p}$ value $<0.001$. However, gender takes no role in COVID-19 severity. As of 345 patients, 19 (5.5\%) died and 326 (94.5\%) recovered. Of patients who died $5.2 \%$ had underlying comorbidities, $3.76 \%$ were females and $1.73 \%$ were males. There was a significant association of age, RT-PCR Ct, underlying comorbidities p value $0.001,0.003$, and $<0.001$ with the risk of mortality. However, we found no significant role of gender in disease mortality $\mathrm{p}$ value $=0.065$.

Out of 345 COVID-19 cases confirmed by RT-PCR; ALT, AST and Gamma G.T was deranged in $31.10 \%, 45.60 \%, 40.80 \%$ patients respectively. However, Albumin 35.90\% and proteins total $2.90 \%$ 
medRxiv preprint doi: https://doi.org/10.1101/2021.09.29.21264304; this version posted October 1, 2021. The copyright holder for this preprint (which was not certified by peer review) is the author/funder, who has granted medRxiv a license to display the preprint in perpetuity.

It is made available under a CC-BY 4.0 International license .

found low in most of the cases. Other parameters e.g., bilirubin total, bilirubin direct, bilirubin indirect were deranged in the small number of patients (Figure 3).

Deritis Ratio It is defined as the activity of AST with ALT (AST/ALT). Only $24.30 \%$ of patients had normal deritis ratio $<1.00$ whereas, it was found raised in $75.70 \%$ of patients.

CRP were raised in $78.90 \%$ and $21.105 \%$ had CRP in normal range.

Table 2 demonstrates the differences for bilirubin (total, direct, indirect), ALP, ALT, AST, albumin, proteins total, GGT, and CRP between asymptomatic, mild, moderate, and severe disease. One way ANOVA result shows that bilirubin indirect, ALT, AST CRP were significantly associated with disease severity.

Deritis ratio and CRP were also found to be significantly associated with the risk of mortality $\mathrm{p}$ value 0.018 and 0.030 respectively.

\section{DISCUSSION}

This study summarizes the RT-PCR Ct/ the viral load of the disease, clinical history, disease severity and other biochemical parameters such as LFTs, Deritis ratio, and CRP in COVID-19 In the present study $51 \%$ males and $49 \%$ females affected with the disease the same results was observed in Jordan et al., 2020 study. According his study (53.4\%) males infected with SARS-CoV-2. Males were more susceptible to SARS-CoV infection as compared to females which could be due to their exposure, higher smoking habits and subsequent comorbidities. ${ }^{(21-23)}$ Mean age was 47.5 years and 36.5\% was in age group 20-40 in our study whereas 49.0-48.0 years in previous studies. ${ }^{(23,24)}$ CDC Director Dr. Rochelle Walensky stated that "hospitals are seeing more and more younger adults" scientists said that new variants of COVID-19 are more transmittable ${ }^{(25)}$ or it could due more exposure of individuals this age with others.

Patients with severe disease shows high viral load, low RT-PCR Ct value. Currently, available confirmatory test for COVID-19 is RT-PCR also considered as gold standard to rule out infection in COVID-19 patients. RT-PCR is very specific, sensitive and rapid technique to detect SARS-CoV-2 RNA. ${ }^{(26)}$ The Ct value of RT-PCR denotes the amplification cycles number that are required by the target 
medRxiv preprint doi: https://doi.org/10.1101/2021.09.29.21264304; this version posted October 1, 2021. The copyright holder for this preprint (which was not certified by peer review) is the author/funder, who has granted medRxiv a license to display the preprint in perpetuity.

It is made available under a CC-BY 4.0 International license.

gene to surpass the threshold level. Previous studies also reported that RT-PCR low Ct value in SARSCoVcould be an important factor related with the disease severity and mortality risk ${ }^{(15)}$ as in our study with $\mathrm{p}$ value $<0.001$ and 0.003 respectively.

COVID-19 infection is very heterogeneous it can vary from asymptomatic to mild, moderate, or severe infection. Other than that, the infection can progress either to way worsening of disease and death or improvement and recovery of the patients. In our study found a significant association between high $\mathrm{Ct}$ value and severity of disease, mortality risk. Most of the individuals affected by COVID-19 only had mild symptoms as in our study $47.20 \%$ were mild cases besides that some patients remain asymptomatic $10.70 \%$ during infection. Data from China, also suggested that $81 \%$ infected Covid-19 patients had mild or moderate disease, and $14 \%$ progress to severe disease. ${ }^{(27)}$ The reason behind this could be their immune status or age as data of case fatality rate (CFR) from Italy which was the first country affected with the pandemic afterwards China. ${ }^{(28)}$ In Pakistan the proportion of people with age 65 years and above was $4.32 \%$ as reported $^{(29)}$ but the higher CFR then China (5.5 vs $2.3 \%$ ) could be due the availability of advance medical facilities. Global reports shows that almost $60 \%$ of deaths were in males ${ }^{(30)}$ that was higher than our study findings where death rate in males were $31.5 \%$.

High risk group of COVID-19 infection and factors that are associated with severe disease includes individuals with age $>70$ and those with underlying comorbidities e.g. diabetes, hypertension, cardiac, liver, respiratory, kidney diseases or chronic lung disease and tumors. ${ }^{(21,31)}$ As previously reported by Li et al and CDC that people with hypertension are more at risk for severe COVID-19 (OR: 2.01; $\mathrm{P}=.003)$ as in our study we also found diabetes $(15.40 \%)$, hypertension $(9.60 \%)$, cardiac disease (5.00\%), asthma $(2.00 \%)$, kidney disease $(1.60 \%)$ and tumor $(0.30 \%)$ of patients. ${ }^{(23,31)}$ Identification of the risk factors that promote the progression towards severe COVID $\square 19$ have great significance for clinicians and for public health policies to deal with the disease.

The most common clinical symptoms of disease observed in this study were fever $78.3 \%$, cough $50.4 \%$, myalgias $50.1 \%$, and shortness of breath in $42.00 \%$ while less common symptoms were headache $19.1 \%$, 
medRxiv preprint doi: https://doi.org/10.1101/2021.09.29.21264304; this version posted October 1, 2021. The copyright holder for this preprint (which was not certified by peer review) is the author/funder, who has granted medRxiv a license to display the preprint in perpetuity.

It is made available under a CC-BY 4.0 International license .

diarrhea $14.8 \%$. Our study shows similar results reported in previous studies by Huang et al and coworkers also reported in his study the most common symptoms were fever $98 \%$, cough $76 \%$, myalgias $44 \%$, shortness of breath $55 \%$ and headache $8 \%$, diarrhea $3 \%$ observed as least common symptoms. ${ }^{(23,24)}$ Elevated levels of ALT (39.4\%), and AST (28.1\%), also abnormal levels of total bilirubin, lower albumin (2.6 vs. 3.4 g/dl, p<0.01) were reported previously. ${ }^{(31-34)}$ However, we found significantly high levels of bilirubin indirect $(\mathrm{P}=0.042)$ transaminases ALT 31.10\% $(\mathrm{P}=0.041)$ and AST45.60 \% $(\mathrm{P}=0.033)$ in our findings. Albumin was also found to be low in $35.90 \%$ but the association was no significant $(\mathrm{P}=0.431)$. The reason for liver damage is still unclear, but some studies show that it could be due to collateral damage due to cytotoxic response during infection as ACE2 receptor the suggested mechanism of virus entrance also present on cholangiocytes, or due to the toxicity from frequently used drugs in those patients. ${ }^{(31,35,36)}$ Deritis ratio (ALT/AST) typically ranges between $0.5-0.7$ generally below $1.0{ }^{(37)}$ In our results it was mostly higher side in almost all the patients with COVID-19 infection. We found a significant association between high Deritis ratio and disease mortality $(\mathrm{P}=0.018)$ that was also reported in some previous studies. ${ }^{(36)}$

In addition to LFTs the levels of CRP that is the marker of tissue damage and inflammation (acute phase protein) respectively ${ }^{(38,39)}$ were found significantly high the patients with severe disease $(\mathrm{CRP} P=0.030)$ in our results. Zinellu et al also reported elevated levels of CRP $(\mathrm{P}<0.05)$ in severe patients ${ }^{(23,32,33,36)}$ So, these parameters can be used as predictive factors for developing cytokine storm/ severe disease and mortality risk. ${ }^{(31)}$

\section{Limitations}

This study was single centered with a small number of patients so, cannot be generalized over the entire population. History of contact, past and current infections, treatment, intubation, and length of hospital stay, must be included to have accurate and complete data on all the risk factors associated with disease and progression towards severe disease. The lack of universal SARS-CoV-2 testing makes it difficult to identify whether people are truly asymptomatic or uninfected. 
medRxiv preprint doi: https://doi.org/10.1101/2021.09.29.21264304; this version posted October 1, 2021. The copyright holder for this preprint (which was not certified by peer review) is the author/funder, who has granted medRxiv a license to display the preprint in perpetuity.

It is made available under a CC-BY 4.0 International license .

\section{Conclusion}

Real-time PCR results for SARS-CoV-2 reported qualitatively (negative or positive) is sufficient for diagnosis but reporting of $\mathrm{Ct}$ values may have benefit for clinicians in patient management decisions. Still, more research is required to support this. Several risk factors for developing severe disease and mortality risk have been identified such as old age, underlying comorbidities such as diabetes and hypertension, etc. The relation between asthma and SARS-CoV-2 severity is not clear and needs further investigation. Deranged LFTs during infection are common and transient. Though, these laboratory parameters ALT, AST, Deritis ratio (AST/ALT), and CRP can be used as predictive biomarkers for progression towards severe disease and risk of mortality

\section{Suggestions}

RT-PCR Ct value link with disease severity needs further investigation. So that, it can be used as a guideline for clinicians. As the data was taken only once, changes over the entire course of disease need to be closely monitored, with treatment history, to explore a more accurate relation between abnormal LFTs and the severity of disease. Further research is needed that either changes in liver enzymes are due to infection or due to treatment. Altogether, the data must be pooled and gathered across countries, so that we can optimize our understanding about the disease.

\section{ACKNOWLEDGMENTS}

I am grateful to Miss Saba Aziz for helping me in statistical analysis of data.

\section{REFERENCES}

1. Helmy YA, Fawzy M, Elaswad A, Sobieh A, Kenney SP, Shehata AA. The COVID-19 Pandemic: A Comprehensive Review of Taxonomy, Genetics, Epidemiology, Diagnosis, Treatment, and Control. 2020;9(4):1225.

2. Srivastava N, Baxi P, Ratho RK, Saxena SK. Global Trends in Epidemiology of Coronavirus Disease 2019 (COVID-19). In: Saxena SK, editor. Coronavirus Disease 2019 (COVID-19):

Epidemiology, Pathogenesis, Diagnosis, and Therapeutics. Singapore: Springer Singapore; 2020. p. 9-21. 3. Guo Y-R, Cao Q-D, Hong Z-S, Tan Y-Y, Chen S-D, Jin H-J, et al. The origin, transmission and clinical therapies on coronavirus disease 2019 (COVID-19) outbreak-an update on the status. 2020;7(1):1-10.

4. Liu Y-C, Kuo R-L, Shih S-RJBj. COVID-19: The first documented coronavirus pandemic in history. 2020. 
medRxiv preprint doi: https://doi.org/10.1101/2021.09.29.21264304; this version posted October 1, 2021. The copyright holder for this preprint (which was not certified by peer review) is the author/funder, who has granted medRxiv a license to display the preprint in perpetuity.

It is made available under a CC-BY 4.0 International license .

5. Gandhi M, Yokoe DS, Havlir DV. Asymptomatic transmission, the Achilles' heel of current strategies to control COVID-19. Mass Medical Soc; 2020.

6. Coronavirus disease 2019 (COVID-19) : epidemiology, pathogenesis, diagnosis, and therapeutics. Saxena SK, editor. Singapore: Springer; 2020.

7. Dil S, Dil N, Maken ZHJC. COVID-19 Trends and Forecast in the Eastern Mediterranean Region With a Particular Focus on Pakistan. 2020;12(6).

8. Mason RJ. Pathogenesis of COVID-19 from a cell biology perspective. Eur Respiratory Soc; 2020.

9. $\quad$ Singhal T. A Review of Coronavirus Disease-2019 (COVID-19). The Indian Journal of Pediatrics. 2020;87(4):281-6.

10. Qi H, Xiao S, Shi R, Ward MP, Chen Y, Tu W, et al. COVID-19 transmission in Mainland China is associated with temperature and humidity: A time-series analysis. 2020:138778.

11. Park M, Cook AR, Lim JT, Sun Y, Dickens BLJJoCM. A systematic review of COVID-19 epidemiology based on current evidence. 2020;9(4):967.

12. Cheng VCC, Lau SKP, Woo PCY, Yuen KY. Severe Acute Respiratory Syndrome Coronavirus as an Agent of Emerging and Reemerging Infection. 2007;20(4):660-94.

13. Zeidler A, Karpinski TMJJJoM. SARS-CoV, MERS-CoV, SARS-CoV-2 comparison of three emerging Coronaviruses. 2020;13(6).

14. Liu F, Li L, Xu M, Wu J, Luo D, Zhu Y, et al. Prognostic value of interleukin-6, C-reactive protein, and procalcitonin in patients with COVID-19. J Clin Virol. 2020;127:104370-.

15. Rao SN, Manissero D, Steele VR, Pareja J. A Narrative Systematic Review of the Clinical Utility of Cycle Threshold Values in the Context of COVID-19. Infectious Diseases and Therapy. 2020;9(3):57386.

16. Huang Y, Yang C, Xu X-f, Xu W, Liu S-w. Structural and functional properties of SARS-CoV-2 spike protein: potential antivirus drug development for COVID-19. Acta Pharmacologica Sinica. 2020;41(9):1141-9.

17. Seah I, Su X, Lingam G. Revisiting the dangers of the coronavirus in the ophthalmology practice. Eye. 2020;34(7):1155-7.

18. Feng G, Zheng KI, Yan Q-Q, Rios RS, Targher G, Byrne CD, et al. COVID-19 and Liver Dysfunction: Current Insights and Emergent Therapeutic Strategies. J Clin Transl Hepatol. 2020;8(1):1824.

19. Jothimani D, Venugopal R, Abedin MF, Kaliamoorthy I, Rela M. COVID-19 and the liver. Journal of hepatology. 2020.

20. Adnan K, Amber F, Yi G, David JK. Lessons to learn from MERS-CoV outbreak in South Korea. The Journal of Infection in Developing Countries. 2015;9(06).

21. Jordan RE, Adab P, Cheng KK. Covid-19: risk factors for severe disease and death. BMJ (Clinical research ed). 2020;368:m1198.

22. Zhang JJ, Cao YY, Tan G, Dong X, Wang BC, Lin J, et al. Clinical, radiological, and laboratory characteristics and risk factors for severity and mortality of 289 hospitalized COVID-19 patients. Allergy. 2021;76(2):533-50.

23. Yu Q, Wang Y, Huang S, Liu S, Zhou Z, Zhang S, et al. Multicenter cohort study demonstrates more consolidation in upper lungs on initial CT increases the risk of adverse clinical outcome in COVID19 patients. Theranostics. 2020;10(12):5641-8.

24. Huang C, Wang Y, Li X, Ren L, Zhao J, Hu Y, et al. Clinical features of patients infected with 2019 novel coronavirus in Wuhan, China. Lancet (London, England). 2020;395(10223):497-506.

25. Walensky DR. Centers for disease control and prevention: Rich Mendez; 2021 [updated APR 7, 2021.

26. Afzal A. Molecular diagnostic technologies for COVID-19: Limitations and challenges. Journal of Advanced Research. 2020;26:149-59.

27. Gandhi RT, Lynch JB, del Rio CJNEJoM. Mild or moderate COVID-19. 2020. 
medRxiv preprint doi: https://doi.org/10.1101/2021.09.29.21264304; this version posted October 1, 2021. The copyright holder for this preprint (which was not certified by peer review) is the author/funder, who has granted medRxiv a license to display the preprint in perpetuity.

It is made available under a CC-BY 4.0 International license .

28. Chen Y, Klein SL, Garibaldi BT, Li H, Wu C, Osevala NM, et al. Aging in COVID-19:

Vulnerability, immunity and intervention. Ageing research reviews. 2021;65:101205.

29. Statistica. Pakistan: Age structure from 2009 to 2019: Aaron O'Neill, Mar 31, 2021; from 2009 to 2019 [

30. Takahashi T, Ellingson MK, Wong P, Israelow B, Lucas C, Klein J, et al. Sex differences in immune responses that underlie COVID-19 disease outcomes. Nature. 2020;588(7837):315-20.

31. Gao YD, Ding M, Dong X, Zhang JJ, Kursat Azkur A, Azkur D, et al. Risk factors for severe and critically ill COVID-19 patients: A review. Allergy. 2021;76(2):428-55.

32. Mori S, Ai T, Otomo Y. Characteristics, laboratories, and prognosis of severe COVID-19 in the Tokyo metropolitan area: A retrospective case series. PLoS One. 2020;15(9):e0239644-e.

33. Malik P, Patel U, Mehta D, Patel N, Kelkar R, Akrmah M, et al. Biomarkers and outcomes of COVID-19 hospitalisations: systematic review and meta-analysis. BMJ evidence-based medicine. 2020.

34. Lei F, Liu YM, Zhou F, Qin JJ, Zhang P, Zhu L, et al. Longitudinal Association Between Markers of Liver Injury and Mortality in COVID-19 in China. Hepatology (Baltimore, Md). 2020;72(2):389-98.

35. Garrido I, Liberal R, Macedo G. Review article: COVID-19 and liver disease-what we know on 1st May 2020. Alimentary pharmacology \& therapeutics. 2020;52(2):267-75.

36. Zinellu A, Arru F, De Vito A, Sassu A, Valdes G, Scano V, et al. The De Ritis ratio as prognostic biomarker of in-hospital mortality in COVID-19 patients. Eur J Clin Invest. 2021;51(1):e13427-e.

37. Paliogiannis P, Zinellu A, Scano V, Mulas G, De Riu G, Pascale RM, et al. Laboratory test alterations in patients with COVID-19 and non COVID-19 interstitial pneumonia: a preliminary report. Journal of infection in developing countries. 2020;14(7):685-90.

38. Sun B, Feng Y, Mo X, Zheng P, Wang Q, Li P, et al. Kinetics of SARS-CoV-2 specific IgM and IgG responses in COVID-19 patients. Emerg Microbes Infect. 2020;9(1):940-8.

39. Yazar H, Kayacan Y, Ozdin M. De Ritis ratio and biochemical parameters in COVID-19 patients. Archives of physiology and biochemistry. 2020:1-5.

\section{FIGURES AND TABLES}

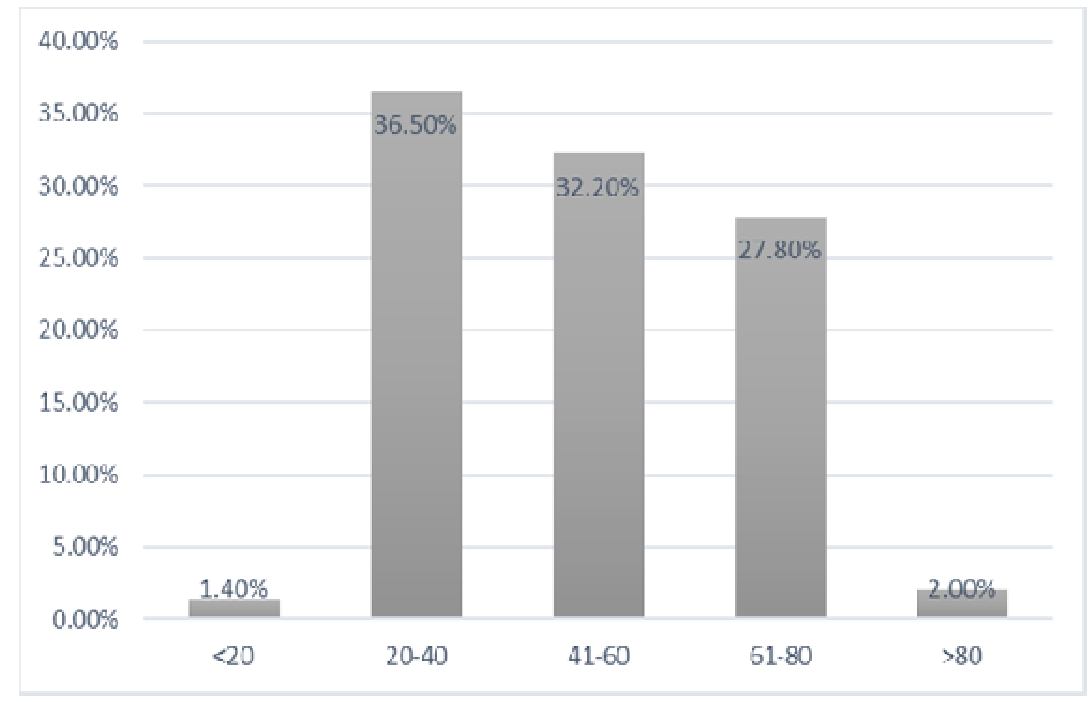

Figure 1 Age Distribution 
medRxiv preprint doi: https://doi.org/10.1101/2021.09.29.21264304; this version posted October 1, 2021. The copyright holder for this preprint (which was not certified by peer review) is the author/funder, who has granted medRxiv a license to display the preprint in perpetuity.

\section{It is made available under a CC-BY 4.0 International license}

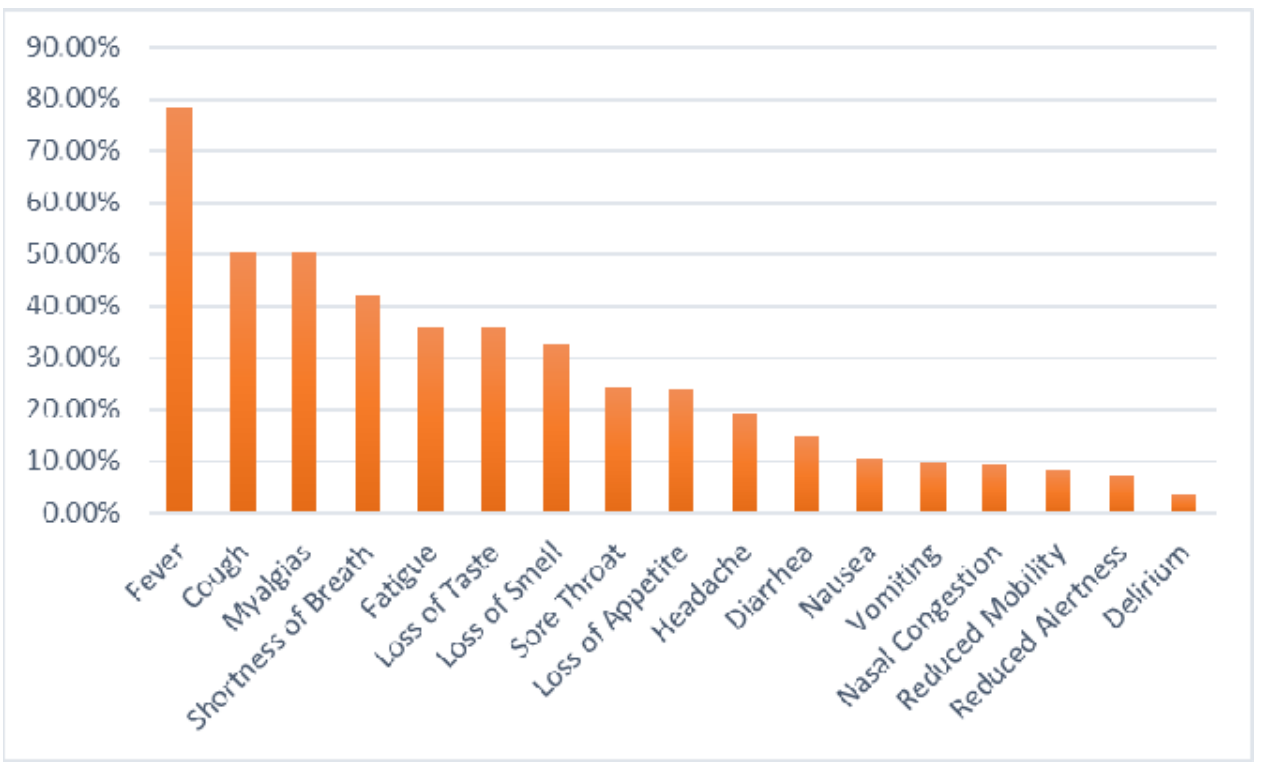

Figure 2 Signs and Symptoms of Disease

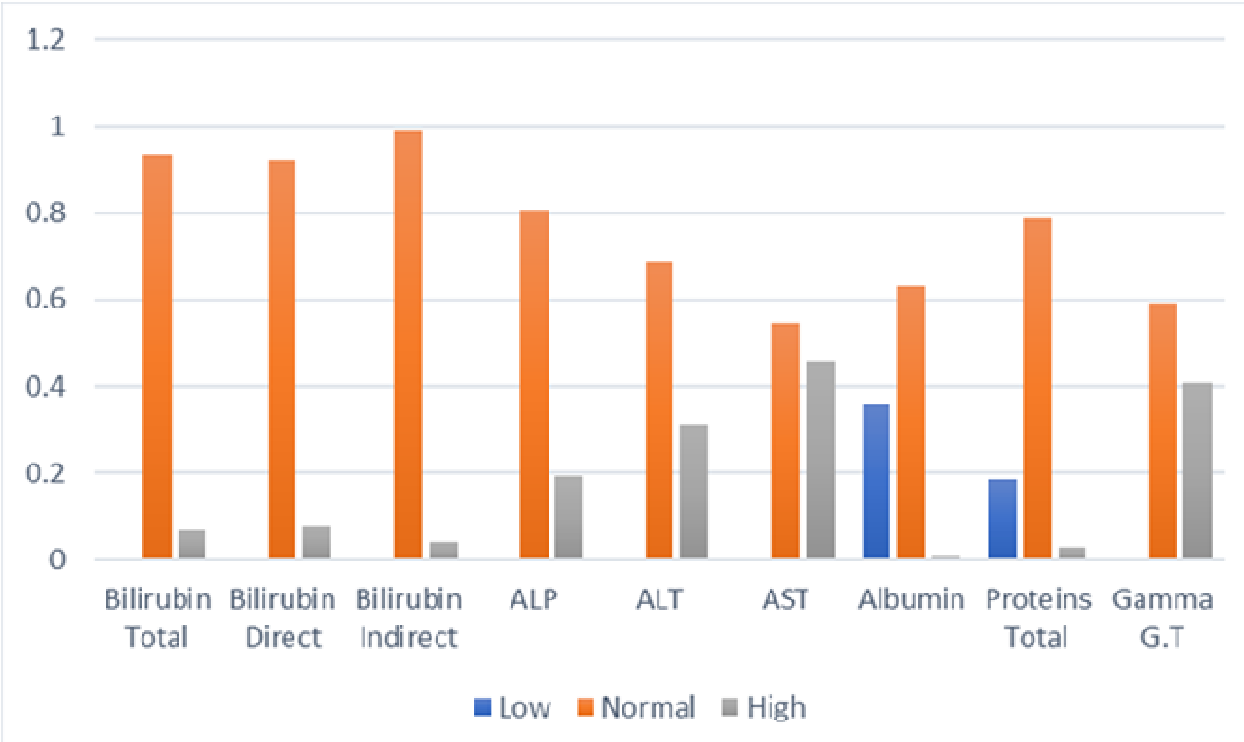

Figure 3 Graphical representation of LFTs parameters in COVID-19 patients 
medRxiv preprint doi: https://doi.org/10.1101/2021.09.29.21264304; this version posted October 1, 2021. The copyright holder for this preprint (which was not certified by peer review) is the author/funder, who has granted medRxiv a license to display the preprint in perpetuity.

It is made available under a CC-BY 4.0 International license.

\begin{tabular}{|c|c|c|c|c|c|}
\hline $\begin{array}{l}\text { Severity } \\
\text { (Number of } \\
\text { Cases) }\end{array}$ & $\begin{array}{l}\text { Asymptomatic } \\
\text { (37) }\end{array}$ & $\begin{array}{l}\text { Mild } \\
(163)\end{array}$ & $\begin{array}{c}\text { Moderate } \\
(115)\end{array}$ & $\begin{array}{l}\text { Severe } \\
(30)\end{array}$ & $P$ value \\
\hline $\begin{array}{l}\text { Gender } \\
\text { Male } \\
\text { Female }\end{array}$ & $\begin{array}{l}15 \\
22\end{array}$ & $\begin{array}{l}83 \\
80\end{array}$ & $\begin{array}{l}66 \\
49\end{array}$ & $\begin{array}{l}12 \\
18\end{array}$ & 0.230 \\
\hline $\begin{array}{l}\text { Age } \\
<20 \\
20-40 \\
40-60 \\
60-80 \\
>80\end{array}$ & $\begin{array}{l}2 \\
19 \\
12 \\
3 \\
1\end{array}$ & $\begin{array}{l}3 \\
63 \\
60 \\
35 \\
2\end{array}$ & $\begin{array}{l}0 \\
41 \\
32 \\
38 \\
4\end{array}$ & $\begin{array}{l}0 \\
3 \\
7 \\
20 \\
0\end{array}$ & $<0.001$ \\
\hline $\begin{array}{l}\text { Comorbidities } \\
\text { Diabetes } \\
\text { Hypertension } \\
\text { Cardiac Disease } \\
\text { Kidney Disease } \\
\text { Asthma }\end{array}$ & $\begin{array}{l}5 \\
2 \\
1 \\
0 \\
0\end{array}$ & $\begin{array}{l}16 \\
11 \\
3 \\
0 \\
3\end{array}$ & $\begin{array}{l}15 \\
13 \\
4 \\
1 \\
4\end{array}$ & $\begin{array}{l}17 \\
7 \\
12 \\
4 \\
0\end{array}$ & $\begin{array}{r}<0.001 \\
0.021 \\
<0.001 \\
<0.001 \\
0.463\end{array}$ \\
\hline
\end{tabular}

age,

comorbidities with

COVID-19 severity 
medRxiv preprint doi: https://doi.org/10.1101/2021.09.29.21264304; this version posted October 1, 2021. The copyright holder for this preprint (which was not certified by peer review) is the author/funder, who has granted medRxiv a license to display the preprint in perpetuity.

It is made available under a CC-BY 4.0 International license.

\begin{tabular}{|l|l|l|l|l|l|}
\hline Tumor & 0 & 0 & 0 & 1 & 0.012 \\
& & & & & \\
\hline
\end{tabular}


medRxiv preprint doi: https://doi.org/10.1101/2021.09.29.21264304; this version posted October 1, 2021. The copyright holder for this preprint (which was not certified by peer review) is the author/funder, who has granted medRxiv a license to display the preprint in perpetuity.

It is made available under a CC-BY 4.0 International license .

Table 2 Results of ANOVA along with Mean \pm SD of Liver Function Test and CRP

\begin{tabular}{|c|c|c|c|c|c|}
\hline Liver Function Test & Asymptomatic & Mild & Moderate & Severe & $\begin{array}{l}\mathrm{P} \\
\text { value }\end{array}$ \\
\hline Bilirubin Total (mg/dl) & $0.5182 \pm 0.2316$ & $\begin{array}{l}0.6842 \pm \\
1.00553\end{array}$ & $\begin{array}{l}0.5028 \pm \\
0.35736\end{array}$ & $\begin{array}{l}1.2444 \pm \\
1.88905\end{array}$ & 0.084 \\
\hline Bilirubin Direct (mg/dl) & $\begin{array}{l}0.2455 \pm \\
0.10357\end{array}$ & $\begin{array}{l}0.2947 \pm \\
0.44048\end{array}$ & $\begin{array}{l}0.2694 \pm \\
0.25837\end{array}$ & $\begin{array}{l}0.7778 \pm 1.4 \\
7471\end{array}$ & 0.053 \\
\hline Bilirubin Indirect (mg/dl) & $\begin{array}{l}0.2727 \pm \\
0.15551\end{array}$ & $\begin{array}{l}0.2474 \pm \\
0.11327\end{array}$ & $\begin{array}{l}0.2333 \pm \\
0.1069\end{array}$ & $\begin{array}{l}0.4667 \pm \\
0.66686\end{array}$ & 0.042 \\
\hline $\begin{array}{l}\text { Alkaline Phosphatase } \\
\text { (U/L) ALP }\end{array}$ & $\begin{array}{l}137.2727 \pm \\
82.91573\end{array}$ & $\begin{array}{l}94.6316 \pm \\
51.86803\end{array}$ & $\begin{array}{l}111.1944 \pm \\
54.21324\end{array}$ & $\begin{array}{l}120.8333 \pm \\
103.009\end{array}$ & 0.244 \\
\hline $\begin{array}{l}\text { Alanine Amino } \\
\text { Transferase (U/L) ALT }\end{array}$ & $\begin{array}{l}21.6364 \pm \\
9.8313\end{array}$ & $\begin{array}{l}26.3684 \pm \\
16.60742\end{array}$ & $\begin{array}{l}77.3333 \pm 142 \\
.938\end{array}$ & $\begin{array}{l}70.2778 \pm \\
32.05841\end{array}$ & 0.041 \\
\hline $\begin{array}{l}\text { Aspartate Amino } \\
\text { Transferase (U/L) AST }\end{array}$ & $21 \pm 5.72713$ & $\begin{array}{l}31.9474 \pm \\
13.13742\end{array}$ & $\begin{array}{l}106.0556 \pm \\
201.9209\end{array}$ & $\begin{array}{l}94.8333 \pm \\
69.16753\end{array}$ & 0.033 \\
\hline Albumin $\mathrm{g} / \mathrm{dl}$ & $\begin{array}{l}4.1182 \pm \\
0.40204\end{array}$ & $\begin{array}{l}4.7395 \pm \\
5.39868\end{array}$ & $\begin{array}{l}3.5639 \pm \\
0.60245\end{array}$ & $\begin{array}{l}3.5667 \pm \\
0.53358\end{array}$ & 0.431 \\
\hline Proteins Total g/dl & $\begin{array}{l}7.0182 \pm \\
1.73195\end{array}$ & $\begin{array}{l}6.9079 \pm \\
0.63219\end{array}$ & $\begin{array}{l}6.8806 \pm \\
0.76525\end{array}$ & $\begin{array}{l}6.8611 \pm \\
0.77698\end{array}$ & 0.968 \\
\hline Gamma G.T (U/L) & $\begin{array}{l}111.1818 \pm \\
164.7136\end{array}$ & $\begin{array}{l}63.1316 \pm \\
64.25505\end{array}$ & $\begin{array}{l}84.6389 \pm \\
73.76223\end{array}$ & $\begin{array}{l}54.1111 \pm \\
89.2148\end{array}$ & 0.26 \\
\hline $\begin{array}{l}\text { C- Reactive Protein } \\
(\mathrm{mg} / \mathrm{dl}) \mathrm{CRP}\end{array}$ & $\begin{array}{l}2.2400 \pm \\
0.61074\end{array}$ & $\begin{array}{l}68.0456 \pm \\
82.06001\end{array}$ & $\begin{array}{l}90.2222 \pm \\
101.32258\end{array}$ & $\begin{array}{l}143.6524 \pm \\
100.00946\end{array}$ & 0.002 \\
\hline
\end{tabular}

